\title{
GREEN MARKETING: THE ENVIRONMENTALLY-FRIENDLY ATTRIBUTES OF PRODUCTS AND DECISION TO PURCHASE
}

Lucyna Witek, Ph.D., Associate Professor

\author{
Rzeszow University of Technology \\ Faculty of Management \\ Department of Marketing \\ Powstańców Warszawy 12, 35-959 Rzeszów, Poland \\ e-mail:lgarbacz@prz.edu.pl \\ ORCID: 0000-0002-8155-0420
}

Received 18 January 2020, Accepted 2 April 2020

\begin{abstract}
Research background: Currently the degradation of the environment which consumers contribute to is an important problem. Purchase behavior plays a key role as it is associated with the choice of products by consumers who are increasingly taking into account environmentally-friendly criteria. The effective implementation of marketing strategies that take into account the principles of sustainable development is possible under the condition of changes in the behavior of purchasers.

Purpose: The purpose of this paper is to analyze the importance of environmentally-friendly attributes for product purchasers.

Research methodology: The research was conducted among 650 Polish consumers. An online survey method was applied.

Results: The study confirms that environmentally-friendly attributes do not play a primary role while choosing products. Hedonic, health and economic benefits take place before environmental benefits. For women, ecofriendly attributes were more important when choosing products, while men were more driven by economic and functional benefits. Young people are hedonists guided by taste and aesthetics, and they do not pay much attention to the environmentally-friendly attributes of products. In turn, older respondents are economical and pragmatic buyers for whom energy efficiency and product durability are of particular importance.

Novelty: The research adds the value as for understanding the phenomenon of the green purchase gap, especially in developing countries where positive attitudes towards green products are not translated into real purchasing behavior. The research quotes some implication for marketing, especially for marketing communication strategies.
\end{abstract}

Keywords: eco-friendly products, green marketing, green purchasing inconsistency, purchase, environmentally-friendly attributes

JEL classification: D46, E31, M31 


\section{Introduction}

In recent years the view on socio-economic development has changed, with attention being drawn to the depletion of natural resources, environmentally damaging production technologies and growing consumption. Changes in thinking and actions that have taken place also apply to enterprises, including the marketing area whose focus is on the purchaser. In addition to quality, price, and commercial criteria (e.g. appearance, packaging), consumers pay attention to other attributes of products, such as health and environmental impact or safety. In this situation, eco-friendly products are a category of products that are gaining importance in the face of environmental degradation and recognition of the concept of sustainable development. In spite of the interest in the market, there is an inconsistency between positive buyers attitudes and actual behavior. A positive attitude to respect for the environment is not covered by real purchasing behavior. Consumers understand the seriousness of environmental issues, but their environmental attitudes do not necessarily lead to the choice of a green product. The existence of the phenomenon of green purchasing inconsistency is confirmed by the numerous studies of many authors (e.g. Follows, Jobber, 2000; Fraj, Martinez, 2006; Gupta, Ogden, 2006; Chatzidakis, Hibbert, Smith, 2007; Pickett-Baker, Ozaki, 2008; Carrington, Neville, Whitwell, 2010; Bray, Johns, Kilburn, 2011; Witek, 2018). Young, Hwang, McDonald and Oates (2010) note that around 30\% of consumers are concerned about environmental issues, but only $5 \%$ translates them into action. In Poland, every third consumer buys organic food, and only for $4 \%$ of the Poles does it constitute the basis of their diets (TNS, 2012).

\section{Literature review}

The product is a basic marketing instrument whose the primary goal is to meet customer needs. A product can also be defined as a set of tangible attributes and intangible values, including packaging, quality, brand and seller services (Fuller, 1999). From the buyer's point of view, the attribute is a carrier of benefits. Kotler (1994) presents the product through the prism of values provided by the manufacturer to the buyer and benefits (usability and pleasure). Buyers do not purchase product features, but benefits. Therefore, the characteristics of an ecological product must be translated into functional, environmental and emotional benefits. The benefits can be defined as a combination of attributes of the product purchased in relation to its individual usefulness for a given buyer. The attribute of an environmentally-friendly product is defined not only by the words "ecological, green", but "environmentally-safe", "recyclable", "biodegradable" or "ozone-friendly", “energy-saving”, “compostable” etc. From the ecological point of view, 
not only environmental, but also functional attributes are important for buyers. Haws, Winterich and Naylor (2014) confirmed the positive correlation between purchases of green products and favorable assessments of non-environmental attributes. The quality, taste and health benefits of the product were described as important attributes for buyers, who buy environmentallyfriendly products (Cerjak, Mesić, Kopić, Kovačić, Markovina, 2010). Buyers associate the attributes of being environmentally-friendly, organic, green with high product quality (Hustvedt, Dickson, 2009).

A review of the literature indicates a different range of understanding of an ecological product. Pabian (2011) indicates that a sustainable product is designed to meet the needs of the buyer, and at the same time throughout its entire life cycle contribute to the achievement of ecological and social goals set by a producer or a seller. Belz and Peattie (2009) point out that the benefits that the product will provide to the buyer and the environment should be taken into account at the design stage of eco-products. An ecological product is seen as a product that does not pollute our planet or impoverish natural resources and can be recycled (Mostafa, 2007). It was noted that green products were usually durable, non-toxic, made from recycled materials or minimally packaged (Ottman, 1998). They generate a less environmental load and provide a higher level of protection compared to conventional products (Dangelico, Pontrandolfo, 2010). Peattie (1995) drew attention not only to the ecological, but also to the social context. A product can be called green, when its environmental and social performance in production, consumption and utilization significantly improves compared to the previous state and is better compared to conventional or competitive product offers (Peattie, 1995). Haws, Winterich and Naylor (2014) define the environmentally-friendly product as a product with at least one positive ecological attribute (the ecological attribute reflects the environmental impact of the product), which may be positive (i.e. the product has no or low environmental impact, then it is considered environmentally-friendly) or negative (i.e. the product harms the environment).

The purpose of the paper is to analyze the importance of environmentally-friendly attributes for product purchasers.

More and more consumers believe that enterprises should have high ethical standards and offer risk-free and safe products (Manget, Roche, Munnich, 2009). Most consumers perceive purchases of environmentally-friendly products as ethical and in line with values (Witek, 2015). A consumer survey in the European Union shows that $54 \%$ of consumers buy environmentallyfriendly products occasionally and $26 \%$ buy them regularly (Eurobarometer, 2013). Consumers buy environmentally-friendly products, because they consider them safer and healthier than 
conventional ones. (Ahmad, 2010). Consumers buy green products, because of their health (Chen, 2009). Based on these findings, hypothesis 1 was adopted.

H1: Purchasers perceive positively environmentally-friendly products and associate them with health and environmental protection.

The attributes of green products are rated higher than price (Rahman, 2019). Manget, Roche and Münnich (2009) showed that buyers highly valued the characteristics of green products, such as taste and freshness, as well as safety and energy cost savings. Some studies show that consumers judge whether or not products are environmentally-friendly based on the quality, price and function of products. These arguments became the basis for the formulation of hypothesis 2 .

H2: The environmentally-friendly attributes of the product are treated as primary by purchasers.

Many studies show that socio-demographic factors influence green purchase behavior. Women are more likely than men to recycle and save energy (Davidson, Freudenburg, 1996). They are more concerned with safety and health, while men understand the environment as a resource for consumption (Olli, Grendstad, Wollebaek, 2001). These attitudes of women translate into stronger intentions to purchase environmentally-friendly products (Urena, Bernabeu, Olmeda, 2008). In line with these findings, hypothesis 3 was adopted.

H3: Ecological attributes were more important for women than for men.

Some studies indicate that the social group most sensitive to environmental issues has a lower age than other groups (D'Souza, Taghian, Lamb, Pretiatko, 2007). The pro-ecological behaviors of young Polish consumers are at a low level, although their attitude towards ecological values is positive (Escher, Petrykowska, 2015). A young consumer, despite being critical of the world around them and a positive attitude to environmental protection, is guided by hedonism, seeking entertainment, pleasure and joy, which is confirmed by the research by Adamczyk (2014). These studies allowed creating hypothesis 4.

H4: Hedonic benefits during purchase are important for young people. The level of proecological behavior increased with age (Gordon-Wilson, Modi, 2015). Some of the attributes of organic food were assessed differently by young and older consumers (GrzybowskaBrzezińska, 2012). Zalega (2016) shows that elderly people perceive durable goods through the prism of their quality, price, brand and utility values. This leads to hypothesis 5 .

H5: Energy efficiency and durability are important for older buyers. 


\section{Research methods}

The research was conducted on a nationwide sample of consumers. An online survey method was used. The quantitative survey was carried out from December 6, 2018 to January 6, 2019. Out of 826 questionnaires, 650 correctly completed questionnaires were accepted for analysis, which also met the assumptions of sample selection. The targeted selection method was used. The province of residence, age of the respondents and gender were the controlled variables. The sample structure corresponded to the population structure by the province of residence and was calculated on the basis of data from the Central Statistical Office. The distribution of the sample in terms of age was very similar to the structure of the nationwide population that has access to the Internet. With regard to the gender it was assumed that $70 \%$ will be women and 30\% men. Women are more often responsible for household purchases (Zasuwa, 2017). The survey covered consumers over 18 years of age interested in buying green products. The structure of the sample is presented in Table 1.

Table 1. Sample of research

\begin{tabular}{|l|l|}
\hline Demographics & Percent (N: 650) \\
\hline Gender & Female: 70, Male: 30 \\
\hline Age & $18-24: 13,25-35: 30,36-45: 28,46-55: 17,55$ and more: 12 \\
\hline Financial situation & Very good: 15, Good: 49, Average: 35, Bad: 2 \\
\hline Education & Higher:61, Secondary: 31, Vocational and less: 8 \\
\hline Place of living & $\begin{array}{l}\text { Village: } 31 ; \text { Town to 40,000: } 19 ; \text { Town from 40,000. to 100,000:13; City from 100,000 } \\
\text { to 500,000; City above 500,000 inhabitants: } 25\end{array}$ \\
\hline
\end{tabular}

Source: own elaboration.

When assessing the attributes of individual product categories, consumers ranked the features from the most important (1) to the least important (7), hence the lower the average ratings, the more important the feature played. The following product categories were assessed: food; household home chemistry; cosmetics; clothes and footwear; household appliances, electronics and computers.

\section{Analysis and results}

Understanding the concept of an environmentally-friendly product is different among consumers. The buyers surveyed most often connected the term with the product's properties, i.e. the lack of pesticides, preservatives, heavy metals, etc. (74\%) and with the production 
of natural ingredients (72\%). To a lesser extent, the term was associated with recycling and biodegradation $(30 \%)$, followed by the terms: a product that protects our health, a high-quality product and a high-price product. Only 3\% paid attention to economy and durability (Figure 1). This feature was particularly noticed by respondents over 55 years of age.

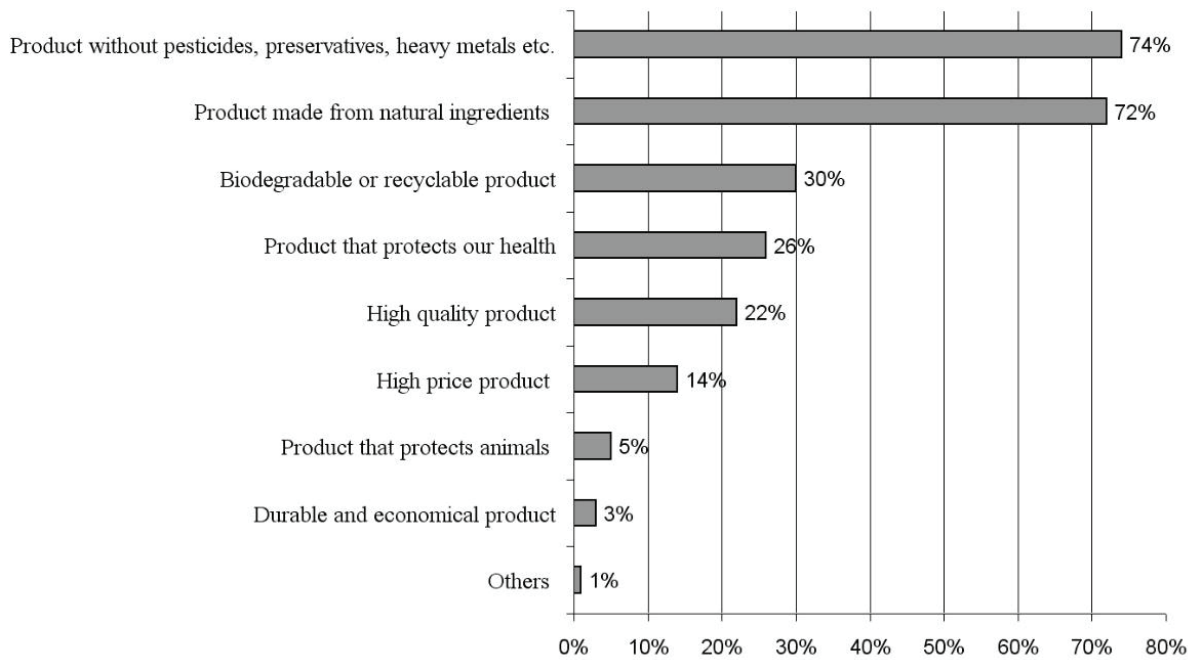

Figure 1. Perception of environmentally-friendly product

Source: own elaboration.

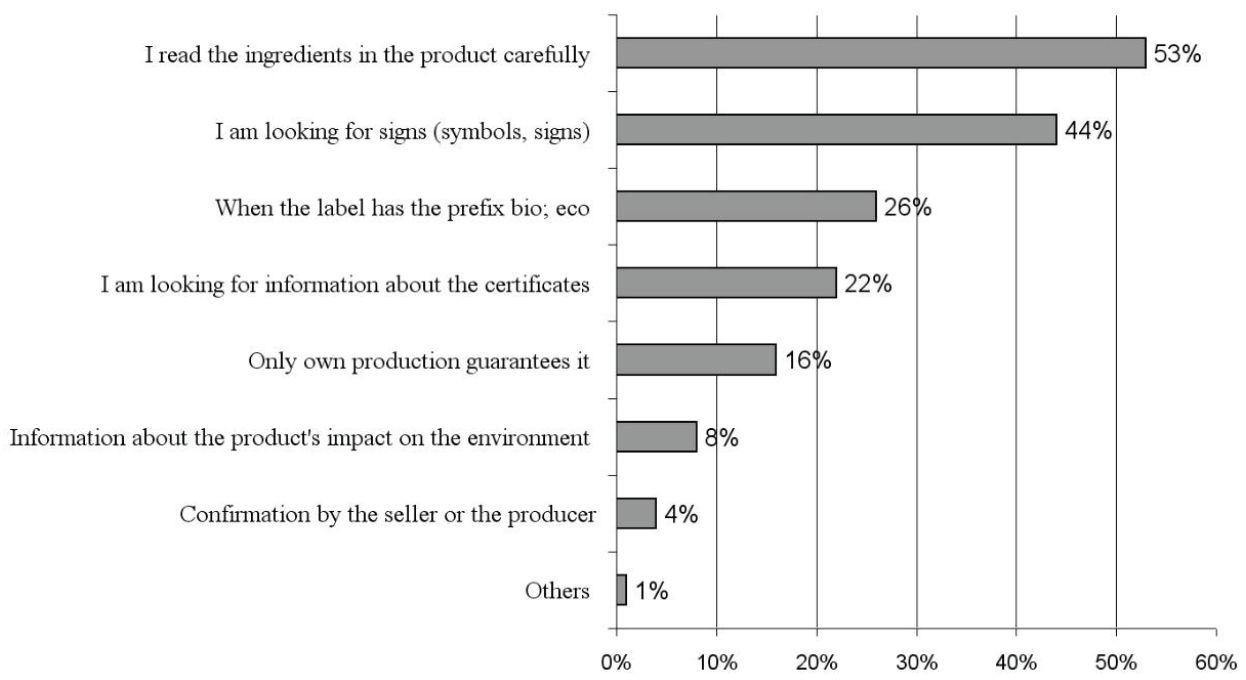

Figure 2. Perception of an environmentally-friendly product

Source: own elaboration. 
The biggest guarantee that the products are green is information on ingredients and symbols (53\%), signs and certificates that it is such a product (44\%). A large group (26\%) pointed to the prefixes -eco, -bio etc. in the name of the product and information on the packaging about attestations and certificates (Figure 2).

An green product is seen as a product that protects the environment and health, and shopping for eco-products gives you a greater sense of security. Purchasers are convinced that they are buying higher quality products. The eco-friendly attributes of the product are not particularly valued by the surveyed consumers. The attributes were ordered by respondents according to their significance when purchasing various products (Table 2). The ecological production method when choosing food was relatively rarely indicated. Only $8.3 \%$ indicated it in the first place, $5.9 \%$ in the second and $7.5 \%$ in the third. In turn, when buying so-called household chemicals respondents pointed to the elimination of freons, halons, chemical compounds, heavy metals (16.2\% indicated it as the most important factor), but already such features as biodegradability and a limited amount of enzymes, phosphates and bleach are less appreciated by the respondents. These attributes in the first place were indicated by $6.5 \%$ and $7.2 \%$ respectively. In the case of cosmetics, consumers pointed to the attribute "not tested on animals". For $14.5 \%$ of buyers, this was the most important factor when choosing these products, but the elimination of freons and halons was less frequently indicated (5.4\%). Clothes made from natural raw materials were particularly valued, while the possibility of recycling or biodegradability and their production from recyclable materials played a smaller role. On the other hand, with regard to durable products, such as home electronics, household appliances, computers, energy efficiency is important for buyers. Durability was less important, and recycling was the least important.

Table 2. Frequency of choosing features first when purchasing products

\begin{tabular}{|c|c|}
\hline Products category & In the first place \\
\hline 1 & 2 \\
\hline Food & $\begin{array}{l}\text { 1. taste }-33.2 \% \\
\text { 2. no preservatives, artificial additives and no GMO }-18.2 \% \\
\text { 3. safety for health }-17.2 \% \\
\text { 4. price }-9.7 \% \\
\text { 5. ecological production method }-8.3 \% \\
\text { 6. without pesticides }-6.9 \% \\
\text { 7. low degree of processing }-6.5 \%\end{array}$ \\
\hline
\end{tabular}




\begin{tabular}{|c|c|}
\hline 1 & 2 \\
\hline Household chemicals & $\begin{array}{l}\text { 1. price }-31 \% \\
\text { 2. safety in use }-17.2 \% \\
\text { 3. elimination of freons and halons and heavy metals- } 16.2 \% \\
\text { 4. efficiency }-13.2 \% \\
\text { 5. brand }-8.8 \% \\
\text { 6. limited amount of enzymes, phosphates, bleaches }-7.2 \% \\
\text { 7. biodegradability }-6.5 \%\end{array}$ \\
\hline Cosmetics & $\begin{array}{l}\text { 1. composition }-25.5 \% \\
\text { 2. health impact }-22.9 \% \\
\text { 3. price }-8.9 \% \\
\text { 4. not tested on animals }-14.5 \% \\
\text { 5. brand }-9.2 \% \\
\text { 6. elimination of freons and halons }-5.4 \% \\
\text { 7. efficiency }-3.5 \%\end{array}$ \\
\hline Clothes and footwear & $\begin{array}{l}\text { 1. comfort }-25.4 \% \\
\text { 2. aesthetics or fashion }-20.8 \% \\
\text { 3. made from natural raw materials, e.g. cotton, silk }-20.8 \% \\
\text { 4. price }-20.2 \% \\
\text { 5. recyclable or biodegradable }-7.4 \% \\
\text { 6. place of production }-3.4 \% \\
\text { 7. made form recyclable materials }-2.2 \%\end{array}$ \\
\hline $\begin{array}{l}\text { Household appliances } \\
\text { and electronics, computers }\end{array}$ & $\begin{array}{l}\text { 1. energy saving }-34.2 \% \\
\text { 2. price vs. quality }-21.9 \% \\
\text { 3. product functions }-12.9 \% \\
\text { 4. durability- } 11.5 \% \\
\text { 5. safety }-11.4 \% \\
\text { 6. aesthetics, appearance }-6.3 \% \\
\text { 7. recyclable- } 1.9 \%\end{array}$ \\
\hline
\end{tabular}

Source: own elaboration.

The Mann-Whitney test showed that some attributes are assessed differently by women and men, as shown in Table 3. When buying food, women attributed greater importance to the attributes: "no preservatives, artificial additives and no GMOs" and "low processing." In turn, when buying so-called household chemicals they drew attention to the "elimination of freons and halons as well as chemicals and heavy metals", "a limited amount of enzymes, phosphates, bleach", while men to "efficiency". When buying cosmetics, women pointed to the information: "composition", "not tested on animals", "elimination of freons and halons", and men paid more attention to "price", "brand" and "performance". On the other hand, when buying clothes, the information "made from natural resources" was more important for women, and "convenience in use" for men. For durable products, "durability" is more important for men than for women. 
Table 3. Mann-Whitney U test results -

gender and average scores of individual attributes of the product

\begin{tabular}{|c|c|c|c|}
\hline Attributes & Female & Male & p-value \\
\hline Food - no preservatives, artificial additives and no GMO & 3.01 & 3.53 & $0.000358 * * *$ \\
\hline Food - low degree of processing & 4.56 & 4.93 & $0.026999 *$ \\
\hline $\begin{array}{l}\text { Household chemicals - elimination of freons and halo- } \\
\text { chemical compounds and heavy metals }\end{array}$ & 3.74 & 4.10 & $0.031859 *$ \\
\hline Household chemicals - efficiency & 3.68 & 3.34 & $0.009982 * *$ \\
\hline Household chemicals - limited amount of enzymes, phosphates, bleach & 4.23 & 4.65 & $0.005837 * *$ \\
\hline Cosmetics - price & 4.21 & 3.61 & $0.001051^{* *}$ \\
\hline Cosmetics - brand & 5.01 & 4.64 & $0.030474 *$ \\
\hline Cosmetics - composition & 2.98 & 3.40 & $0.007015^{* *}$ \\
\hline Cosmetics - not tested on animals & 3.90 & 4.44 & $0.001290 * *$ \\
\hline Cosmetics - efficiency & 4.40 & 3.99 & $0.001141 * *$ \\
\hline Cosmetics - elimination of freons and halons & 4.68 & 5.07 & $0.038536^{*}$ \\
\hline Clothes and shoes - price & 3.64 & 3.27 & $0.047050^{*}$ \\
\hline Clothes and shoes - comfort & 2.89 & 2.50 & $0.005268 * *$ \\
\hline Clothes and shoes - made from natural raw materials, e.g. cotton, silk & 3.05 & 3.68 & $0.000014 * * *$ \\
\hline Household appliances and electronics, computers - durability & 3.54 & 3.22 & $0.010355^{* * *}$ \\
\hline
\end{tabular}

$* \mathrm{p}<0.05-$ there is a statistically significant relationship, ${ }^{* *} \mathrm{p}<0.01-$ there is a highly statistically significant relationship, ${ }^{* * *} \mathrm{p}<0.001-$ that is very much highly statistically significant relationship.

Source: own elaboration.

Age turned out to be a factor differentiating the assessment of some attributes (Table 4). The youngest respondents paid the most attention to the taste of food, and the least the oldest. However, the opposite was true for the green production method. The older the surveyed, the more ecological production method was appreciated. People aged 18-24 mostly paid attention to the price when buying food, household chemicals and cosmetics, but when buying household chemicals safety and performance were also important to them. In turn, the elimination of freons, halons, heavy metals etc. as well as biodegradability, recycling and energy efficiency were not important for them. When buying clothes, respondents paid attention to aesthetics. The older the respondents, the less the aesthetics played a role, and the greater the energy efficiency and durability of durable products. In turn, the lack of pesticides, preservatives, artificial additives, etc. in food was most noticed by respondents aged 36-45, but when buying household chemicals safety for health was not very important for them. 
Table 4. Results of the Kruskal-Wallis ANOVA test age and average scores of individual statements

\begin{tabular}{|c|c|c|c|c|c|c|}
\hline \multirow[b]{2}{*}{ Attributes } & \multicolumn{5}{|c|}{ Age } & \multirow[b]{2}{*}{ p-value } \\
\hline & $18-24$ & $25-35$ & $36-45$ & $46-55$ & $\begin{array}{l}\text { more than } \\
55\end{array}$ & \\
\hline Food - taste & 2.32 & 3.43 & 3.24 & 3.44 & 3.60 & $0.0003 * * *$ \\
\hline Food - ecological production method & 5.28 & 5.08 & 4.83 & 4.47 & 4.45 & $0.0080 * *$ \\
\hline Food - price & 3.69 & 4.23 & 4.63 & 4.79 & 4.45 & $0.0022 * *$ \\
\hline Food - without pesticides & 4.61 & 4.07 & 3.84 & 3.91 & 4.10 & $0.0166^{*}$ \\
\hline $\begin{array}{l}\text { Food - no preservatives, artificial additives } \\
\text { and no GMO }\end{array}$ & 3.81 & 3.20 & 2.89 & 3.06 & 3.18 & $0.0043 * *$ \\
\hline Household chemicals - safety & 3.28 & 3.52 & 4.00 & 3.48 & 3.35 & $0.0127^{*}$ \\
\hline Household chemicals - price & 2.71 & 3.36 & 3.58 & 3.56 & 3.65 & $0.0274 *$ \\
\hline $\begin{array}{l}\text { Household chemicals - elimination of freons } \\
\text { and halons and heavy metals }\end{array}$ & 4.61 & 3.71 & 3.65 & 3.94 & 3.69 & $0.0021 * *$ \\
\hline Household chemicals - biodegradability & 5.00 & 4.93 & 4.30 & 4.28 & 4.66 & $0.0010^{* *}$ \\
\hline Household chemicals - efficiency & 3.00 & 3.45 & 3.83 & 3.84 & 3.57 & $0.0024 * *$ \\
\hline Cosmetics - price & 3.61 & 3.98 & 4.42 & 3.87 & 3.91 & $0.0367 *$ \\
\hline Cosmetics - not tested on animals & 4.36 & 4.17 & 3.65 & 4.20 & 4.21 & $0.0207 *$ \\
\hline $\begin{array}{l}\text { Cosmetics - elimination of freons and halons and } \\
\text { heavy metals }\end{array}$ & 5.39 & 4.89 & 4.43 & 4.76 & 4.79 & $0.0166^{*}$ \\
\hline Clothes and shoes - recyclable or biodegradable & 5.47 & 4.89 & 4.69 & 4.81 & 4.71 & $0.0138 *$ \\
\hline Clothes and shoes - aesthetics or fashion & 2.93 & 3.30 & 3.42 & 3.61 & 3.68 & $0.0288^{*}$ \\
\hline Clothes and shoes - made form recyclable materials & 3.35 & 2.91 & 2.64 & 2.50 & 2.69 & $0.0099 * *$ \\
\hline $\begin{array}{l}\text { Household appliances and electronics, computers - } \\
\text { energy saving }\end{array}$ & 4.28 & 4.28 & 3.91 & 3.91 & 3.65 & $0.0350 *$ \\
\hline $\begin{array}{l}\text { Household appliances and electronics, computers - } \\
\text { safety in use }\end{array}$ & 3.21 & 3.28 & 3.70 & 3.52 & 3.44 & $0.0341^{*}$ \\
\hline $\begin{array}{l}\text { Household appliances and electronics, computers } \\
\text { - durability }\end{array}$ & 2.75 & 3.06 & 3.40 & 3.31 & 4.00 & $0.0007 * * *$ \\
\hline
\end{tabular}

Source: own elaboration.

The material situation also influenced the assessment of various attributes of products (Table 5). The better the material situation, the smaller the price. The elimination of freons and halons in cosmetics turned out to be more important for people who have a good financial situation. The worse the material situation, the more important the price-quality ratio was. Among the inhabitants of small towns, the attribute "made of recyclable materials" and "durability" played an important role (Table 6). In turn, the inhabitants of large cities appreciated the poor degree of food processing and clothing aesthetics. 
Table 5. Results of the Kruskal-Wallis ANOVA test material situation and average grades individual attributes

\begin{tabular}{|l|c|c|c|c|c|}
\hline \multicolumn{1}{|c|}{ Attributes } & Bad & Average & Good & Very good & p-value \\
\hline Food - price & 2.91 & 4.22 & 4.38 & 5.02 & $0.0010^{* *}$ \\
\hline Household chemicals - price & 2.09 & 3.19 & 3.37 & 4.17 & $0.0003^{* * *}$ \\
\hline Cosmetics - price & 2.55 & 3.78 & 4.07 & 4.65 & $0.0070^{* *}$ \\
\hline $\begin{array}{l}\text { Cosmetics - elimination of freons and halons } \\
\text { and heavy metals }\end{array}$ & 6.18 & 4.74 & 4.88 & 4.48 & $0.0234^{*}$ \\
\hline $\begin{array}{l}\text { Household appliances and electronics, } \\
\text { computers- price }\end{array}$ & 2.36 & 3.37 & 3.51 & 4.06 & $0.0076^{* *}$ \\
\hline $\begin{array}{l}\text { Household appliances and electronics, } \\
\text { computers - price vs. quality }\end{array}$ & 2.18 & 3.12 & 3.27 & 3.71 & $0.0205^{*}$ \\
\hline
\end{tabular}

Source: own elaboration.

Table 6. Results of the Kruskal-Wallis ANOVA test place of residence and average scores of individual statements

\begin{tabular}{|l|c|c|c|c|c|c|}
\hline \multicolumn{1}{|c|}{ Attributes } & Village & $\mathrm{T} 1$ & $\mathrm{~T} 2$ & $\mathrm{~T} 3$ & $\mathrm{~T} 4$ & $\mathrm{p}$-value \\
\hline Food - low degree of processing & 4.82 & 4.46 & 5.12 & 4.84 & 4.34 & $0.0312 *$ \\
\hline Clothes and shoes - made form recyclable materials & 5.47 & 5.12 & 4.92 & 5.55 & 5.60 & $0.0070 * *$ \\
\hline Clothes and shoes - aesthetics or fashion & 3.56 & 3.48 & 3.60 & 3.08 & 3.11 & $0.0482 *$ \\
\hline $\begin{array}{l}\text { Household appliances and electronics, computers } \\
- \text { durability }\end{array}$ & 3.59 & 3.17 & 3.78 & 3.43 & 3.32 & $0.0352 *$ \\
\hline
\end{tabular}

Source: own elaboration.

Research shows that environment-friendly attributes do not play a primary role, when choosing products. Hedonic, health and economic benefits take first place before environmental benefits. For women, pro-ecological attributes were more important when choosing products, while men were more driven by economic and functional benefits. Young people are hedonists guided by taste and aesthetics, not paying much attention to the ecological attributes of products. In turn, older respondents are economical and pragmatic buyers, for whom energy efficiency and product durability are of particular importance.

\section{Discussion and conclusion}

Biel and Dahlstrand (2005) suggest that the barrier to the introduction of ecological marketing is the relatively large cognitive effort of buyers required to translate the values associated with sustainable development into the purchase of ecological products. The Harvard 
Business Review Poland study (2017) shows, that the concept of a circular economy is little known. As many as $71 \%$ of respondents did not know this concept or never met it. Of those $29 \%$ of respondents who heard about this, most people (57\%) associate the circular economy with the possibility of reducing waste, and only $28 \%$ with eco-designing products. These premises point to the important role of the product as a marketing tool and a new look at the organic product in relation to buyers, whose main goal is to inform about the product's features, attract attention and encourage purchase. Hence, two product approaches should be distinguished: commercial and technical, which are complementary but completely different approaches. Technical terms used to determine the nature of an organic product are not known to buyers, which increases the distance between the organic product and the customer. These difficulties are further compounded because the ecological product is a dynamic category with a high level of complexity.

Environmental motives compete with stronger needs and desires. The motives for buying green products are concentrated in the area of environmental protection and health. In all countries where buyer surveys were conducted, they declare similar purchase motives. Among them is the health theme first, followed by concern for the state of the environment. Not all the hypotheses were confirmed. The research results show how purchases of ecological products are strongly dependent on factors related to care for one's own health (e.g. Chryssohoidis, Krystallis, 2005). Most studies indicate the importance of health motivation, although the study of Tsarenko, Ferraro, Sands and McLeod (2013) indicate altruistic motives as the main motivating factors for buying eco-products. In the light of previous research on eco-food, it is perceived as food characterized primarily by healthy values, which is associated with the indicated motives for its purchase. Gutkowska and Ozimek (2005) claim that as much as 95.7\% of respondents indicated a health motive, and only in fourth place concern for the state of the environment. Bryła (2016) emphasizes not only health aspects, but also the ecological nature of the product, food safety considerations, excellent taste and quality. Sojkin \& Witczak (2009) show that, in addition to caring for health, the diet used is the primary reason for purchasing it. Jarczok-Guzy (2018) indicates the health and production method (no preservatives). Purchasing environmentally products is associated not only with safety, but also generativeness, i.e. caring for other people, apart from yourself and your family.

Consumers will buy an ecological product, when the original needs for the product's functional features, e.g. performance, quality, convenience and availability, are met. For there to be a strong link between attitudes and real behavior toward eco-friendly products, there must be other factors, such as direct product experience, knowledge of the benefits of purchasing eco-products, and trust that must be built by providing clear, complete and reliable information. 
The product's environmental attributes are harder to evaluate by the buyer compared to other easily observable product features.

Buyers are often not convinced that the production method was in fact compatible with the principles of respect for the environment. The "ecological" attribute is strongly associated with the "healthy" and "safe" attribute. Functional and durable product properties combined with high product quality have a positive impact on the purchasing behavior of ecological products. On the other hand, the weaknesses of the eco-product, e.g. worse taste, lower efficiency can cause a conflict between the individual needs of buyers and a sense of responsibility for the environment, which can further increase the inconsistency between the attitude and the intention to buy and the behavior of purchasers. Information asymmetries are also an important factor hindering the purchase of ecological products. The buyer will be more willing to pay more for a product based on its ecological attribute, if some value added to the product is offered, e.g. better taste, safety or financial benefits (e.g. lower gas bills).

The choice of an ecological production method is associated with the process of creating a new product, which requires the use of other marketing strategies. One of the directions of marketing activities aiming at changing the attitudes of buyers towards ecological products is the strategy of increasing the buyer's conviction that the eco-brand has important features. Actions are also required to communicate the attributes of eco-products.

Green marketing is considered to be one of the main aspects of modern businesses. It is a strategic marketing approach in which companies pay attention to their activities for the environment. It is seen as a holistic strategic management practice that meets the needs of consumers and does not have the negative impact on human well-being or other elements of the environment. An environmentally friendly product is increasingly associated with human well-being, which is also an element of the environment, hence the development of sustainable marketing. Martin and Schouten (2012) point out that it is a process of creating, communicating and delivering value to consumers in a way that protects and strengthens the natural environment and human capital. This new look at how to create value, deliver them and communicate to clients and society, the principles of cooperation with suppliers and recipients, the implementation of various marketing functions, as well as the analysis and minimization of the adverse impact of these activities on the socio-ecological environment is a good introduction to combining sustainable concepts development and marketing, and to change the often negative perception of marketing.

Purchasers will increasingly expect ecological products from producers and at the same time products that do not cause social problems. The condition is changes in the awareness and 
attitudes of not only customers but producers and distributors as well as changes in the approach to strategic management (Rudawska, 2013). An interesting research for the future could be to examine the impact of social and ethical attributes on purchasing decisions and comparisons with eco-friendly attributes. The results obtained in this paper are based on consumer declarations, which may distort the real situation.

\section{References}

Adamczyk, G. (2014). Wybrane aspekty zachowań młodych konsumentów w nowych realiach rynkowych (Selected aspects of young consumer behavior in the new market realities). Handel Wewnętrzny, 1 (354), 5-16.

Ahmad, S.N.B.B. (2010). Organic food: A study on demographic characteristics and factors influencing purchase intentions among consumers in Klang Valley, Malaysia. International Journal of Business and Management, 5 (2), 105-118.

Belz, F.M., Peattie, K. (2009). Sustainability Marketing. A Global Perspective. Chichester: Willey.

Biel, A., Dahlstrand, U. (2005). Values and habits: A dual process model. In: S. Krarup, C.S. Russell (eds.), Environment, Information and Consumer Behaviour (pp. 33-50). Cheltenham: Edward Elgar.

Bray, J., Johns N., Kilburn D. (2011). An exploratory study into the factors impeding ethical consumption. Journal of Business Ethics, 98 (4), 597-608. DOI: 10.1007/s10551-0100640-9.

Bryła, P. (2016). Organic food consumption in Poland: motives and barriers. Appetite, 105, 737-746. DOI: 10.1016/j.appet.2016.07.012. PMid:27417333.

Carrington, M., Neville, B., Whitwell, G. (2010). Why Ethical Consumers Don't Walk Their Talk: Towards a Framework for Understanding the GAP between the Ethical Purchase Intentions and Actual Buying Behaviour of Ethical Minded Consumer. Journal of Business Ethics, 97, 139-158. DOI: 10.1007/s10551-010-0501-6.

Cerjak, M., Mesić, Ž., Kopić, M., Kovačić, D., Markovina, J. (2010). What motivates consumers to buy organic food: Comparison of Croatia, Bosnia, Herzegovina, and Slovenia. Journal of Food Products Marketing, 16 (3), 278-292. DOI: 10.1080/10454446.2010.484745.

Chatzidakis, A., Hibbert, S., Smith, A.P. (2007). Why people don't take their concerns about fair trade to the supermarket: The role of neutralization. Journal of Business Ethics, 74 (1), 89-100. DOI: 10.100710551-006-9222-2. 
Chen, T.B., Chai, L.T. (2010). Attitude towards the environment and green products: Consumers' perspective. Management science and engineering, 4 (2), 2-39.

Chryssohoidis, G.M., Krystallis, A. (2005). Organic Consumers' Personal Values Research: Testing and Validating the List of Values (LOV) Scale and Implementing a Valuebased Segmentation Task. Food Quality and Preference, 16, 585-599. DOI: 10.1016/j. foodqual.2005.01.003.

Davidson, D.J., Freudenburg, W.R. (1996). Gender and environmental risk concerns: a review and analysis of available research. Environmental Behavior, 28 (3), 302- 339. DOI: 10.1177/0013916596283003.

Dangelico, R.M., Pontrandolfo, P. (2010). From green product definitions and classifications to the green option matrix. Journal of Cleaner Production, 18 (16-17), 1608-1628. DOI: 10.1016/j.jclepro.2010.07.007.

D’Souza, C., Taghian, M., Lamb, P., Pretiatko, R. (2006). Green decisions: demographics and consumer understanding of environmental labels. International Journal of Consumer Studies, 31 (4), 371-376. DOI: 10.1111/j.1470-6431.2006.00567.x.

European Commission (2013). Attitudes of Europeans towards building the single market for green products. Eurobarometer, 367. Retrieved from: http://ec.europa.eu/commfrontoffice/publicopinion/flash/fl367en.pdf (30.09.2020).

Escher, I., Petrykowska, J. (2015). Proekologiczne zachowania młodych polskich konsumentów (Pro-ecological behaviours of young Polish consumers. Handel Wewnętrzny, 2 (355),128141.

Follows, S.B., Jobber, D. (2000). Environmentally Responsible Purchase Behavior: A Test of A Consumer Model. European Journal of Marketing, 34 (5/6), 723-746. DOI: DOI: 10.1108/03090560010322009.

Fraj, E., Martinez, E. (2006). Influence of personality on ecological consumer behavior. Journal of Consumer Behaviour, 5, 167-181. DOI: 10.1002/cb.169.

Fuller, D. (1999). Sustainable Marketing. Managerial-Ecological Issues. California: SAGE.

Gordon-Wilson, S., Modi, P. (2015). Personality and Older Consumers' Green Behaviour in the UK. Futures, 71, 1-10.

Grzybowska-Brzezińska, M. (2012). Zachowania młodych konsumentów i seniorów na rynku żywności ekologicznej (Behaviour of young consumers and seniors on organic food market). Zeszyty Naukowe Uniwersytetu Szczecińskiego. Problemy Zarzadzania, Finansów i Marketingu, 25, 211-222.

Gupta, S., Ogden, D. (2006). The Attitude-Behaviour-Gap in Environmental Consumerism. APUBEF Proceedings - Fall, 199-206. 
Gutkowska, K., Ozimek, I. (2005). Wybrane aspekty zachowań konsumentów na rynku żywności - kryteria zróżnicowania (Selected aspects of consumer behavior in the food market - differentiation criteria). Warszawa: SGWW.

Harvard Business Review Polska (2018). Działania proekologiczne Polaków a ich wiedza na temat gospodarki obiegu zamkniętego (Pro-ecological activities of the Poles and their knowledge about the circular economy), 10.

Haws, K.L., Winterich, K.P., Naylor R.W. (2014). Seeing the world through GREEN-tinted glasses: Green consumption values and responses to environmentally friendly products. Journal of Consumer Psychology, 24 (3), 336-354. DOI: DOI: 10.1016/j.jcps.2013.11.002.

Hustvedt, G., Dickson, M.A. (2009). Consumer likelihood of purchasing organic cotton apparel: influence of attitudes and self-identity. Journal of Fashion Marketing and Management, 13 (1), 49-65. DOI: 10.1108/13612020910939879.

Jarczok-Guzy, M. (2018). Obstacles to the development of the organic food market in Poland and the possible directions of growth. Food Science \& Nutrition, 6 (6), 1462-1472. DOI: 10.1002/fsn3.704.

Kotler, Ph. (1994). Marketing. Analiza, planowanie, wdrażanie i kontrola (Marketing. Planning, analysis, implementation and control). Warszawa: Gebertner \& Ska.

Manget, J., Roche, C., Munnich, F. (2009). Capturing the green advantage for consumer companies. Report: Boston Consulting Group, January.

Martin, D., Schouten, J. (2012). Sustainable Marketing. New Jersey: Prentice Hall.

Mostafa, M.M. (2007). Gender differences in Egyptian consumers' green purchase behaviour: The effects of environmental knowledge, concern and attitude. International Journal of Consumer Studies, 31 (3), 220-229. DOI: 10.1111/j.1470-6431.2006.00523.x.

Olli, E., Grendstad, G., Wollebaek, D. (2001). Correlates of Environmental Behaviors. Bringing Back Social Context. Environment and Behavior, 33 (2), 181-208. DOI: 10.1177/0013916501332002.

Ottman, J.A. (1998). Green Marketing: Opportunity For Innovation Second edition. Book Surge, Chicago: NTC/Contemporary Publishing Company.

Pabian, A. (2011). Strategia produktu w zrównoważonej działalności marketingowej (Product strategy in sustainable marketing). Zeszyty Naukowe Uniwersytetu w Poznaniu, 172, 148-158.

Peattie, K. (1995). Environmental Marketing Management. London: Pitman Publishing.

Pickett-Baker, J., Ozaki, R. (2008). Pro-environmental products: marketing influence on consumer purchase decision. Journal of Consumer Marketing, 25, 281-293. DOI: 10.1108/07363760810890516. 
Rahman, M.S. (2019). Green products' attributes and price: how do they affect consumers' green purchasing behavior and loyalty status in Bangladesh? Journal on Management, $13(3), 1-10$.

Rudawska, E. (2013). Marketing zrównoważony - nowe oblicze kapitalizmu? (Sustainable marketing - the new face of capitalism?). Ekonomia, 3 (24), 75-88.

Sojkin, B., Witczak, J. (2009). Konsument żywności ekologicznej w dużym mieście. In: A. Graczyk, K. Mazurek-Łopacińska (eds.), Badanie rozwoju rynków produktów rolnictwa ekologicznego i żywności ekologicznej w Polsce (pp.156-168) (Ecological food consumer in a large city. Research into the development of eco-farming and eco-food markets in Poland). Wrocław: Uniwersytet Ekonomiczny.

TNS (2012). 30\% Polaków deklaruje, że kupuje żywność ekologiczną. Retrieved from: http:// biokurier.pl/jedzenie/tns-polska-30-polakow-deklaruje-ze-kupuje-zywnosc-ekologiczna (27.12.2018).

Tsarenko, Y., Ferraro, C., Sands, S., McLeod C. (2013). Environmentally conscious consumption: The role of retailers and peers as external influences. Journal of Retailing and Consumer Services, 20 (3), 302-310. DOI: 10.1016/j.jretconser.2013.01.006.

Witek, L. (2018). Green consumer: the attitude-behavior gap towards environmentally friendly products. In: F. Bylok, A. Albrychiewicz-Słocińska, L. Cichobłaziński (eds.), Book of Proceedings ICoM 2018, 8th International Conference On Management: Leadership, Innovativeness and Entrepreneurship in a Sustainable Economy (pp. 654-659). Częstochowa: Politechnika Częstochowska.

Witek, L. (2015). Zachowania konsumentów na rynku produktów ekologicznych w Polsce i innych krajach Unii Europejskiej (Consumers' Behaviours in the Market for Ecological Products in Poland and Other European Union Countries). Handel Wewnętrzny, 1, 281-289.

Urena, F., Bernabeu, R., Olmeda, M. (2008). Women, Men and Organic Food: Differences in Their Attitudes and Willingness to Pay: A Spanish Case Study. Journal of Consumer Studies, 32 (1), 18-26. DOI: 10.1111/j.1470-6431.2007.00637.x.

Young, W., Hwang, K., McDonald, S., Oates, C.J. (2010). Sustainable Consumption: Green Consumer Behaviour when Purchasing Products. Sustainable Development, 18, 20-31. DOI: $10.1002 /$ sd.394.

Zalega, T. (2016). Zachowania konsumenckie osób starszych w Polsce (Consumer behavior of the elderly in Poland. Handel Wewnętrzny, 2 (361), 410-422.

Zasuwa, G. (2017). Znaczenie wartości w prospołecznych zachowaniach konsumentów. Kontekst marketingu społecznie zaangażowanego (The importance of values in pro-social consumer behavior. The context of socially engaged marketing). Lublin: Wydawnictwo KUL. 